\title{
Exploiting the Future: The Evolution of Child Labour Laws in Ontario from the Pre-Industrial Period to the 1930s
}

\section{Daniel Moholia}

$\underline{\text { Introduction }}$

According to the United Nation's Convention on the Rights of a Child, children can participate in labour, so long as "the work is not detrimental to [their] health, personal development, or education...". While child labour is still prominent in developing countries, with 250 million children between 5 and 14-years-old working, at one point in time Canada dealt with a child labour crisis. ${ }^{2}$ This article will examine the evolution of child labour laws in the Canadian province of Ontario with respect to the social, economic, and political factors that shaped our cultural and legal understanding of childhood and children's rights. Child labour laws in Ontario evolved significantly during the nineteenth and early twentieth-century as social conceptualizations of childhood changed, the economic landscape shifted with industrialization and modernization, and the legal battles of authority and enforcement ensued between government and private businesses.

\section{Child Labour and Childhood in Preindustrial Canada}

While child labour is highly stigmatized in most cases today, prior to industrialization in the $19^{\text {th }}$ century it was not uncommon for children to work at home or on the family farm. Children tended to help with simple tasks like cooking and cleaning, pulling weeds, and digging. ${ }^{3}$ Child labour was not only an economic necessity for the financial stability of the family but also desired out of a belief that temptation to do immoral things was strongest when

\footnotetext{
${ }^{1}$ Soo Nam, "Child Labour in Latin America," Law and Business Review of the Americas 19, no. 4 (2013): 524.

${ }^{2}$ Ibid, 523.

${ }^{3}$ Carolyne Tuttle, Hard at Work in Factories and Mines (Boulder, CO: Westview Press, 1999), 9.
} 
the mind and body were idle. The upper classes thus sought education to subdue their child's mind, while the lower classes resorted to physical labour to subdue their child's body. ${ }^{4}$ Children sometimes left home as early as 7-years-old to pursue education or apprenticeship positions, ${ }^{5}$ with records indicating that parents would indenture their children as early as the 1550 s in Britain. ${ }^{6}$ The practice crossed the Atlantic as early as 1619 , when a group of impoverished and orphaned children were transported to the newly-settled Virginia colony to work as apprentices. ${ }^{7}$

While the concept of "childhood" did not exist as it does today, it would be an unwarranted assumption to think that parents saw no distinction between their children and adults. For many centuries prior to and including the period of Western settlement, the cultures of European countries considered certain ages, such as seven, fourteen, and eighteen, to be milestones in a child's life in transition to adulthood. ${ }^{8}$ This is reflected even in the work that children did around the home or on the farm. In recognition of their reduced physical and mental capacity, work tended to be light and required little skill. While it was clear that work could be physically strenuous, the idea that work could shape (or distort) the mental and emotional capacities of a child was not yet common.

Since this mentality was pervasive throughout society, it was inevitably reflected in the actions of government officials. As late as the 1850s, the family was considered to be the semiautonomous sphere of governance of the father, meaning that any state interference with the father's authority was considered to be an intrusion by the government in an area of society in

\footnotetext{
${ }^{4}$ Pamela Horn, Children's work and welfare, 1780-1890 (Melbourne, AU: Press Syndicate of the University of Cambridge, 1994), 1.

${ }^{5}$ Richard Wall, “The Age at Leaving Home,” Journal of Family History 3, no 2 (1978): 183.

${ }^{6}$ Carolyne Tuttle, Hard at Work in Factories and Mines (Boulder, CO: Westview Press, 1999), 9.

${ }^{7}$ Chaim M. Rosenberg, Child Labor in America (Jefferson, NC: McFarland \& Company, 2013), 33.

${ }^{8}$ Margatta Rahikainen, Centuries of Child Labour (Hampshire, GB: Ashgate Publishing Limited, 2004$), 12$.
} 
which they had no business. ${ }^{9}$ The unspoken assumption was that the father, as the one responsible for the family, had both the proximity to understand the minute details of family affairs as well as their best interests at heart.

\section{$\underline{\text { Industrialization and Legal Liability }}$}

With industrialization and urbanization, children became employed in various locations outside the home, such as factories, mills, mines, ${ }^{10}$ shops,${ }^{11}$ and farms not belonging to their families. ${ }^{12}$ As a result, the labour relations at play in a child's employment changed as contracted apprenticeships decreased in popularity ${ }^{13}$ and the sprawling network of factories and shops sought children for the performance of unskilled, cheap labour work which came with little government oversight. ${ }^{14}$ The child's master had profit in mind, without any legally binding contract to demand a duty of care or reasonable grounds to assume that they would be concerned for the child's safety.

Part of the demand for child labour with industrialization came with the mechanization of many industries, resulting in the need for unskilled workers to operate machines that would do the skilled work. ${ }^{15}$ Children were seen as submissive and energetic workers who were easy to train and recruit and would accept lower wages than adult males by doing the same work. ${ }^{16}$ As a result of the sheer number of children working in the various industries by the end of the nineteenth century, legislation that regulated child labour was seen as detrimental to the national

\footnotetext{
${ }^{9}$ Pamela Horn, Children's work and welfare, 1780-1890 (Melbourne, AU: Press Syndicate of the University of Cambridge, 1994), 4.

${ }^{10}$ Robert McIntosh, Boys in the Pits (Montreal, QC and Kingston, ON: McGill-Queen's University Press, 2000), 4.

${ }^{11}$ Canada. Department of Labour, Legislative Branch. Labour Legislation in Canada [Ottawa], 1945. 15.

${ }^{12}$ Gwynth Joy Parr, The Home Children (Ann Arbor, MI: University Microfilms International, 1977), v.

${ }^{13}$ Lorna F. Hurl, "Restricting Child Factory Labour in Late Nineteenth Century Ontario," Journal of Canadian Labour Studies 21, no. 2 (1988): 90.

${ }^{14}$ Carolyne Tuttle, Hard at Work in Factories and Mines (Boulder, CO: Westview Press, 1999), 82.

${ }^{15}$ Ibid, 8.

${ }^{16}$ Ibid, 79-80.
} 
economy. It is for this reason that, for example, the Royal Commission on Mills and Factories of 1882 conceded that child labour conditions were unhealthy and strenuous yet made no recommendation as it did not want to create a competitively disadvantageous business environment for domestic industry. ${ }^{17}$ The cheap employment of children increased margins as it drove down the wages of unskilled labour positions, impacting the ability of many families to survive off of the salary of one wage earner and thus necessitating that women and children contribute to the family economy. ${ }^{18}$ Child labour essentially created its own supply and demand. Before long, certain groups and organizations called for regulation.

Demands for regulation were not as sweeping as one may think. The most ardent opponents of child labour were the labour unions. They recognized the need to regulate hazardous working conditions for children, yet went beyond that and demanded that the minimum age of an employable worker be raised to reduce competition for adult workers and thus prevent wages from being driven even further down. ${ }^{19}$ For this reason, in the 1890 s the Trades and Labour Congress went beyond regulation and demanded that children be barred from working up until the age of $14 .{ }^{20}$ While the National Council of Women, a child-saver organization, supported the Trades and Labour Congress' 1883 bid for legislation regulating factory work, their objective was regulation, not criminalization. ${ }^{21}$ Even the Children's Aid Societies operated by child welfare proponents argued as late as the 1890s that boys should be

\footnotetext{
${ }^{17}$ Lorna F. Hurl, "Restricting Child Factory Labour in Late Nineteenth Century Ontario," Journal of Canadian Labour Studies 21, no. 2 (1988): 94.

${ }^{18}$ Ibid, 116-7.

${ }^{19}$ Lorna F. Hurl, "Restricting Child Factory Labour in Late Nineteenth Century Ontario," Journal of Canadian Labour Studies 21, no. 2 (1988): 94.

${ }^{20}$ Robert McIntosh, Boys in the Pits (Montreal, QC and Kingston, ON: McGill-Queen's University Press, 2000), 25.

${ }^{21}$ Ibid.
} 
self-sufficient at age 14 and girls at age $12 .{ }^{22}$ A healthy childhood was not one without labour, but rather one without physically, mentally, and emotionally damaging labour.

Efforts for the legal regulation of child labour in factories commenced towards the end of the $19^{\text {th }}$ century with varying degrees of success. While not resolving the issues with child labour all together, it established legal liability within the industry for the safety and well-being of children.

The Canadian Parliament attempted to pass eight different versions of a factory act regulating child labour from 1879 to 1886 , yet the Canadian Manufacturers' Association managed to stall and eventually kill the bill by arguing that the matter was outside federal jurisdiction. ${ }^{23}$ The provincial legislatures were then left with the responsibility to regulate. In 1884, Ontario passed The Ontario Factories' Act,${ }^{24}$ which prohibited boys younger than 12 and girls younger than 13 from working in factories, ${ }^{25}$ and limited child labour to no more than 10 hours a day, or 60 hours a week. ${ }^{26}$ It was deemed illegal to employ a child if their health was "likely to be permanently injured", with the punishment being six months in prison or $\$ 100$ in jail plus prosecution costs. ${ }^{27}$

While legislation was passed quickly, its enforcement was quite a different question. On the one hand were the problems of enforceability. The Ontario Factories' Act (1884) required that age-verifying physician-approved certificates be kept on record for boys 12 to 14 -yearsold ${ }^{28}$ yet many parents sought to falsify certificates to have their children employed at a younger

\footnotetext{
${ }^{22}$ John Bullen, "Hidden Workers," Journal of Canadian Labour Studies 18, no. 3 (1986): 180.

${ }^{23}$ Lorna F. Hurl, "Restricting Child Factory Labour in Late Nineteenth Century Ontario," Journal of Canadian Labour Studies 21, no. 2 (1988): 93-4.

${ }^{24}$ Government of Ontario, Ontario Statutes of 1884, The Ontario Factories' Act, 1884, 1884, s. 1, 146.

${ }^{25}$ Ibid, s. 6(1), 149.

${ }^{26}$ Ibid, s. 6(3), 149.

${ }^{27}$ Ibid, s. 5, 148.

${ }^{28}$ Ibid, s. 4, 148.
} 
age, undeterred by the risk of being fined under the new Act. ${ }^{29}$ The system proved to be ineffective, and so The Factories Amendment Act of 1895 raised the minimum age of employment in a factory to 14 for both sexes. ${ }^{30}$ On the other hand, there was a degree of sympathy for the manufacturers. The only court case between the 1884 Act's proclamation in 1886 and 1889 was brought against the canning industry, and sympathies were so strong with the defendant that an 1887 amendment of the Act provided exemption from part of the Factory Act to the canning industry from July to September of every year. ${ }^{31}$

In yet other cases, despite school attendance for four months a year being made compulsory for children ages 7 to 21 in $1871,{ }^{32}$ inspectors sympathized with the extreme poverty of some families. In 1885, all public schooling had become free for those ages 5 to 21 years old, ${ }^{33}$ and mandatory for at least 100 days of every school year, yet reasonable grounds for exemption included "extreme poverty." "34 This gave the Public School Inspector the power to reduce the necessary quota of school days to 50 a school year for children who lived in extreme poverty. ${ }^{35}$

Beyond the sympathies of the inspector lay the question of the inspection capacity of the hired inspectors. While Ontario expanded the application of factory regulations to any factories employing at least five people, it had only three hired inspectors to enforce the law provincewide. It was not until 1893 that this was addressed by mandating that municipalities appoint an

\footnotetext{
${ }^{29}$ Ibid, s. 17, 153.

${ }^{30}$ Government of Ontario, Ontario Statutes of 1895, The Factories Amendment Act, 1895, 1895, s. $12,330$.

${ }^{31}$ Government of Ontario, Ontario Statutes of 1887, An Act to amend The Ontario Factories' Act, 1884, 1887, s. 2, 167-8.

${ }^{32}$ Robert McIntosh, Boys in the Pits (Montreal, QC and Kingston ON: McGill-Queen's University Press, 2000 ), 33.

${ }^{33}$ Government of Ontario, Ontario Statutes of 1885, The Public Schools Act, 1885, 1885, s. 6, 197.

${ }^{34}$ Ibid, s. $217,249$.

${ }^{35}$ Government of Ontario, Ontario Statutes of 1885, The Public School Act, 1885, 1885, s. 212, 248.
} 
officer to carry out inspections of factories. ${ }^{36}$ As enforcement of the factory law improved, though, other industries were left behind.

Ontario passed The Ontario Shops' Regulation Act in $1888,{ }^{37}$ with an 1897 amendment prohibiting children under 10 from working in shops, ${ }^{38}$ yet home working establishments were exempted from the law. ${ }^{39}$ This was the case in spite of the fact that major urban centres like Toronto had many home working textile shops working under contract, ${ }^{40}$ some employing children for 16-18 hours a day. ${ }^{41}$ An investigation by the federal government in 1896 discovered that working conditions were far poorer in these home work establishments than in factories and shops regulated by law.

In spite of the growth of the child-savers movement and the introduction of compulsory school attendance laws, instances of cheap child labour in factories and shops became more prevalent throughout the economic depression of the $1870 \mathrm{~s}$ and $1880 \mathrm{~s}^{42}$ With the age of modernization commencing in the 1890 s, child labour instances dropped by $51.1 \%$ across Ontario. ${ }^{43}$ With the modernization of industry, mergers stabilized market prices in certain sectors, thereby reducing the incentive for cheap labour and driving up the demand for skilled labour to aid in the expansion of industry which could not be filled by unskilled children. ${ }^{44}$ Due

\footnotetext{
${ }^{36}$ Government of Ontario, Ontario Statutes of 1893, An Act for the Prevention of Cruelty to, and Better Protection of Children, 1893, s. 1, 175.

${ }^{37}$ Government of Ontario, Ontario Statutes of 1888, The Ontario Shop's Regulation Act, 1888, s. 1, 80.

${ }^{38}$ Government of Ontario, Ontario Statutes of 1897, An Act respecting Shops and Places other than Factories, 1897, s. 4, 492 .

${ }^{39}$ John Bullen, "Hidden Workers," Journal of Canadian Labour Studies 18, no. 3 (1986): 173.

${ }^{40}$ Robert McIntosh, Boys in the Pits (Montreal, QC and Kingston, ON: McGill-Queen's University Press, 2000$), 4$.

${ }^{41}$ John Bullen, "Hidden Workers," Journal of Canadian Labour Studies 18, no. 3 (1986): 171.

${ }^{42}$ Lorna F. Hurl, "Restricting Child Factory Labour in Late Nineteenth Century Ontario," Journal of Canadian Labour Studies 21, no. 2 (1988): 113.

${ }^{43}$ Ibid, 112.

${ }^{44}$ Lorna F. Hurl, "Restricting Child Factory Labour in Late Nineteenth Century Ontario," Journal of Canadian Labour Studies 21, no. 2 (1988): 113.
} 
to the increased value of skilled labour, more families were able to live off the wages of the father's skilled labour and fewer children had to contribute to the family economy. ${ }^{45}$

As more families could afford to send their children to school, vocational institutions opened, providing boys with manual and technical training. High schools also became more common in certain communities, ${ }^{46}$ providing training for the expanding white-collar job market. $^{47}$

The Cultural and Political Strategy Shift of the $20^{\text {th }}$ Century

By the $20^{\text {th }}$ century, the values around childhood had changed significantly. Children were painted as weak and incapable of taking care of themselves, thus needing the support of adults. ${ }^{48}$ This attitude is exemplified in the October $30^{\text {th }}, 1906$ letter by M. Doersster of South Dakota to the Canadian Prime Minister's Office. She wrote to warn the government of the plans of a Westhouse mica mill due to open in Custer, South Dakota to solicit child labour from the Canadian prairie provinces. She vehemently affirmed that "Canada has a grander work for her children than to have them murdered in a Mica plant" and likens the Westhouse business to Satan's church attempting to enslave and slowly kill the offspring of the nation. ${ }^{49}$

While more families began sending their children to school, for some working-class families it was still a luxury to be able to do so. It would not be until the 1920s that unskilled factory workers would make a living wage high enough to sustain a family on. ${ }^{50}$ In spite of this, child-savers argued that the only way poverty could be eliminated was through education. This

\footnotetext{
${ }^{45}$ Ibid. 115.

${ }^{46}$ Government of Ontario, Ontario Statutes of 1891, The High Schools Act, 1891, 1891, s. 37, 187.

47 John Bullen, “Hidden Workers,” Journal of Canadian Labour Studies 18, no. 3 (1986): 184.

${ }^{48}$ Robert McIntosh, Boys in the Pits (Montreal, QC and Kingston, ON: McGill-Queen's University Press, 2000$), 5$.

${ }^{49}$ Library and Archives Canada. Volume 431, Reel C-839. Sir Wilfrid Laurier Fonds, Correspondence. 115088-9.

${ }^{50}$ Lorna F. Hurl, "Restricting Child Factory Labour in Late Nineteenth Century Ontario," Journal of Canadian Labour Studies 21, no. 2 (1988): 116.
} 
tension between the economically stable of society and those struggling to survive persisted for many decades into the $20^{\text {th }}$ century. ${ }^{51}$ Some of the upper classes believed that those not sending their children to school, regardless of their motive, were being cruel parents. ${ }^{52}$ As economically difficult times came with the Great Depression and the 1960s, many deeply rooted patterns of child labour persisted despite government efforts to change them. ${ }^{53}$ The road to success in this avenue had quite a few bumps along the way.

Education was seen as the venue through which the poverty-stricken of society could be lifted to higher financial existences. The Ontario government focused its efforts on public elementary and high school restructuring in the early decades of the $20^{\text {th }}$ century, attempting to force attendance rates up and draw children out of the labour market and into classrooms. In 1909, truancy laws were enacted to better keep track of the absences from class of children 8 to 14-years-old, those required to attend school full-time. ${ }^{54}$ The government then shifted its focus to artificially raising the age of employment by creating grounds for compulsory school attendance among adolescents. In 1912, The Adolescent School Attendance Act permitted local Boards of Education to enact by-laws requiring compulsory attendance of day or evening classes by adolescents 14 to $17 .{ }^{55}$ By 1919 , adolescents 14 to 16 were expected to attend school full time, ${ }^{56}$ only being exempted by attaining home permits that indicated their guardian needed them to be at home to work. ${ }^{57}$ Even with home permits, they needed to accumulate at least 400 hours of class attendance every year, in stark contrast to the leniency of previous laws. ${ }^{58}$ Adolescents 16

\footnotetext{
${ }^{51}$ Jeremy P. Felt, Hostages of Fortune (Syracuse, NY: Syracuse University Press, 1965), 38.

52 Tony Newman, "Workers and Helpers," British Journal of Social Work 30, no. 3 (2000): 328.

${ }^{53}$ Neil Sutherland, "'We always had things to do'," Journal of Canadian Labour Studies 25, no. 2 (1990): 107.

${ }^{54}$ Government of Ontario, Ontario Statutes of 1909, The Truancy Act, 1909, s. 3, 585.

${ }^{55}$ Government of Ontario, Ontario Statutes of 1912, The Adolescent School Attendance Act, 1912, s. 2 (a), 729.

${ }^{56}$ Government of Ontario, Ontario Statutes of 1919, The Adolescent School Attendance Act, 1919, 1919, s. 3(1), 413.

${ }^{57}$ Ibid, s. 4(1), 414.

${ }^{58}$ Ibid, s. 6, 414.
} 
to 18 could only be employed by presenting a school dismission or registration card. ${ }^{59}$ By 1921 , high schools were free to attend, ${ }^{60}$ though poverty remained grounds for exemption from school as late as $1945 .{ }^{61}$ While the government was idealistic in its endeavours, it nonetheless recognized the difficult decisions that some parents inevitably had to make.

Upon enacting more stringent school laws, Ontario dealt with loopholes in its factory laws by repealing the exemption of the canning industry from some sections of the Factories Act in $1918 .{ }^{62}$ All children under the age of 14 were banned from engaging in any form of employment in 1919, which was meant to strengthen the enforcement of truancy laws by further reducing the grounds on which a child, defined as one under the age of 14, could be exempted from compulsory school attendance. ${ }^{63}$ As of 1928 , apprenticeships could only be entered into by adolescents at least 16 -years-old, ${ }^{64}$ with the Ontario government banning employment of all children and adolescents under 16 during school hours in shops and factories the following year in 1929. It would not be until 1964 that the performance of home work without a permit from an inspector would be banned. ${ }^{65}$ As such, many of the home industries persisted, though domestic demand decreased as the outsourcing of much of the textile industry around the world was cheaper and more competitive for businesses. Slowly but surely, Canada went through economic development which eventually deemed child labour "unnecessary and undesirable."66

\footnotetext{
${ }^{59}$ Government of Ontario, Ontario Statutes of 1919, The Adolescent School Attendance Act, 1919, 1919, s. $8,415$.

${ }^{60}$ Government of Ontario, Ontario Statutes of 1921, The School Law Amendment Act, 1921, 1921, s. $15(42)(1), 313$.

${ }^{61}$ Canada. Department of Labour, Legislative Branch. Labour Legislation in Canada [Ottawa], 1945. 15.

${ }^{62}$ Government of Ontario, Ontario Statutes of 1918, The Factory, Shop and Office Building Act, 1918, s. 9, 315.

${ }^{63}$ Government of Ontario, Ontario Statutes of 1919, An Act to amend The Children's Protection Act, 1919, s. 5, 362.

${ }^{64}$ Government of Ontario, Ontario Statutes of 1928, The Apprenticeship Act, 1928, s. 12(a), 61.

${ }^{65}$ Government of Ontario, Ontario Statutes of 1970. An Act to amend The Industrial Safety Act, 1964, 1970, s. 27(1), 181.

${ }^{66}$ Steve Cunningham, and Michael Lavalette, "Children's Rights or Employers' Rights?," in Thatcher's

Grandchildren?, eds. Stephen Wagg and Jane Pilcher (Houndsmill, UK: Palgrave Macmillan, 2014), 278.
} 


\section{$\underline{\text { Conclusion }}$}

The history of child labour in Ontario evolved through gradual legal reform and gradual change of societal perceptions of children and their place in society. Children prior to the late $19^{\text {th }}$ century were considered economic assets, indebted to their parents for raising them and thus responsible to an extent for the economic status and available finances of the family. The childsaver movement sought to portray childhood as a time of vulnerability and dependence rather than of economic productivity, setting standards for all classes to aspire to in raising their children despite the impoverished situation of many working-class families. The provincial government responded by establishing the legal liability of employers with regards to how they treat child workers and of parents with regards to sending their children to school on a regular basis. Slowly but surely, as education was made a more significant part of childhood, the minimum age of an employable individual rose to 14-years-old, which is where it remains in the present day. 


\section{Bibliography}

Bullen, John. "Hidden Workers: Child Labour and the Family Economy in Late NineteenthCentury Urban Ontario,” Journal of Canadian Labour Studies 18, no. 3 (1986): 163-187.

Canada. Department of Labour, Legislative Branch. Labour Legislation in Canada: A Historical Outline of the Principal Dominion and Provincial Labour Laws [Ottawa], 1945.

Cunningham, Steve and Michael Lavalette, "Children's Rights or Employers' Rights?: The 'Destigmatisation' of Child Labour." in Thatcher's Grandchildren?: Politics and Childhood in the Twenty-First Century, eds. Stephen Wagg and Jane Pilcher, 275-300. Houndsmills, UK: Palgrave Macmillan, 2014.

Felt, Jeremy P. Hostages of Fortune: Child Labour Reform in New York State, Syracuse, NY: Syracuse University Press, 1965.

Government of Ontario, Ontario Statutes of 1893, An Act for the Prevention of Cruelty to, and Better Protection of Children, 1893, 175.

Government of Ontario, Ontario Statutes of 1897, An Act respecting Shops and Places other than Factories, 1897, 493-500.

Government of Ontario, Ontario Statutes of 1919, An Act to amend The Children's Protection Act, 1919, 362.

Government of Ontario, Ontario Statutes of 1970, An Act to amend The Industrial Safety Act, 1964, 1970, 257.

Government of Ontario, Ontario Statutes of 1887, An Act to amend The Ontario Factories' Act, $1884,1887,167-8$.

Government of Ontario, Ontario Statutes of 1912, The Adolescent School Attendance Act, 1912, 729.

Government of Ontario, Ontario Statutes of 1919, The Adolescent School Attendance Act, 1919, 1919, 413-5.

Government of Ontario, Ontario Statutes of 1928, The Apprenticeship Act, 1928, 1928, 61.

Government of Ontario, Ontario Statutes of 1895, The Factories Amendment Act, 1895, 1895, 328-330.

Government of Ontario, Ontario Statutes of 1918, The Factory, Shop and Office Building Act, 1918, 1918, 315. 
Government of Ontario, Ontario Statutes of 1891, The High Schools Act, 1891, 1891, 188.

Government of Ontario, Ontario Statutes of 1884, The Ontario Factories' Act, 1884, 1884, 147158.

Government of Ontario, Ontario Statutes of 1888, The Ontario Shops' Regulation Act, 1888, $1888,80-85$.

Government of Ontario, Ontario Statutes of 1885, The Public Schools Act, 1885, 1885, 197-248.

Government of Ontario, Ontario Statutes of 1921, The School Law Amendment Act, 1921, 1921, 313.

Government of Ontario, Ontario Statutes of 1909, The Truancy Act, 1909, 585-6.

Horn, Pamela. Children's work and welfare, 1780-1890. Melbourne, AU: Press Syndicate of the University of Cambridge, 1994.

Hurl, Lorna F. "Restricting Child Factory Labour in Late Nineteenth Century Ontario," Journal of Canadian Labour Studies 21, no. 2 (1988): 87-121.

Library and Archives Canada. Volume 431, Reel C-839. Sir Wilfrid Laurier Fonds. Correspondence.

McIntosh, Robert. Boys in the Pits: Child Labour in Coal Mines. Montreal, QC and Kingston, ON: McGill-Queen's University Press, 2000.

Nam, Soo. "Child Labor in Latin America," Law and Business Review of the Americas 19, no. 4 (2013): 523-549.

Newman, Tony. "Workers and Helpers: Perspectives on Children's Labour 1899-1999," British Journal of Social Work 30, no. 3 (2000): 323-338. doi: 10.1093/bjsw/30.3.323.

Parr, Gwynth Joy. The Home Children: British Juvenile Immigrants to Canada, 1868-1924. Ann Arbor, MI: University Microfilms International, 1977.

Rahikainen, Marjatta. Centuries of Child Labour: European Experiences from the Seventeenth to the Twentieth Century. Hampshire, GB: Ashgate Publishing Limited, 2004.

Rosenberg, Chaim M. Child Labor in America: A History. Jefferson, NC: McFarland \& Company, 2013.

Sutherland, Neil. "'We always had things to do': The Paid and Unpaid Work of Anglophone Children Between the 1920s and the 1960s," Journal of Canadian Labour Studies 25, no. 2 (1990): 105-141. 
Tuttle, Carolyne. Hard at Work in Factories and Mines: The Economics of Child Labor During the British Industrial Revolution. Boulder, CO: Westview Press, 1999.

Wall, Richard. “The Age at Leaving Home,” Journal of Family History 3, no. 2 (1978): 181-202. doi: 10.1177/036319907800300206. 